\title{
Effect of Intercropping and Fertility Levels on Yield Attributes, Yield and Economics of Summer Pearlmillet (Pennisetum glaucum L.) under South Gujarat Condition
}

\author{
K. R. Patel*, J. D. Thanki and P. H. Kalal \\ Department of Agronomy Farm, N. M. College of Agriculture, Navsari Agricultural \\ University, Navsari, India \\ *Corresponding author
}

\section{A B S T R A C T}

Keywords

Pearlmillet, Grain yield, straw yield, pearlmillet equivalent yield, RDF

Article Info

Accepted:

20 May 2021

Available Online:

10 June 2021
A field experiment was conducted at College Agronomy Farm, N. M. College of Agriculture, Navsari Agricultural University, Navsari during summer, 2019 and 2020 comprising four intercropping treatments i.e. pearlmillet sole, pearlmillet+greengram, pearlmillet+cowpea, pearlmillet+clusterbean and three fertility levels viz., $75 \%$ RDF, $100 \%$ RDF and $125 \%$ RDF. Significantly higher number of tillers per hill, dry matter accumulation per plant at 60 DAS and at harvest, number of earheads per hill, earhead length, grain and straw yields of pearl millet were noted in pearl millet + green gram intercropping in both the years of investigation as well as in pooled analysis. Whereas pearl millet equivalent yield was significantly highest in pearl millet + green gram $\left(\mathrm{I}_{2}\right)$ intercropping system. In case of fertility levels, significantly higher values of plant height, number of tillers per hill at 60 DAS and harvest, dry matter accumulation per plant at 60 DAS and harvest, number of ear heads per hill, ear head girth, grain yield, straw yield, pearl millet equivalent yield were recorded in $100 \% \mathrm{RDF}\left(\mathrm{F}_{2}\right)$ treatment.

\section{Introduction}

Pearlmillet, locally called as bajra is an important dual purpose crop as its grain is used for human consumption and its fodder as cattle feed. It ranks fourth after rice, wheat and sorghum and is grown in almost all the states of the country. Limited availability of land resources and the decline in the soil fertility has increased the importance of the ability of agriculture to sustain the increasing demand of the population both globally and locally. To counter the demand, we have to look for ways which enhance the use of currently available resources than in the past. Intercropping is one promising practise which is effective to 
augment the total productivity per unit area of the land per unit time by growing more than one crop in the same field with an objective of better utilization of environmental resources. The basic concept of intercropping involves growing together two or more crops with the assumption that two crops can exploit the environment better than one and ultimately produce higher yield (Reddy and Willy, 1981). Cereal- pulses intercropping has attracted the attention of agronomists, possibly as a result of the established and theoretical advantages of intercropping systems (Ofori and Stern, 1978). Intercropping with pulses is a practice in which $\mathrm{N}$ fixed by latter enhances the qualitative and quantitative traits of the former to finally reach food security and sustainability (Swaminathan, 1998). Pulses such as cowpea, clusterbean and greengram are known to fix the atmospheric nitrogen with the help of rhizobium bacteria and it supplies the cereal crop with the required nitrogen. Fertilizer management is one of the important cost effective factors known to augment the crop production. Hence, inclusion of pulses in any intercropping system has becomes imperative with the overall view of maintaining soil fertility and for economizing fertilizer use.

\section{Experimental materials and methods}

The field experiment was conducted during summer season of both the years 2019 and 2020 at N. M. College of Agriculture, Navsari Agricultural University, Navsari. The soil of the experimental field was clayey in texture, low in organic carbon content $(0.41 \%)$ and available nitrogen $(199.86 \mathrm{~kg} / \mathrm{ha})$, medium in available phosphorus (39.43 kg/ha) and fairly high in available potassium $(302.88 \mathrm{~kg} / \mathrm{ha})$. The soil was slightly alkaline in reaction $(\mathrm{pH}$ 7.9). The experiment was laid out in factorial randomized block design with 12 combinations comprising of four intercropping treatments (pearlmillet sole, pearlmillet + greengram, pearlmillet + cowpea and pearlmillet + clusterbean) and three fertility levels $(75 \%, 100 \%$ and $125 \%$ of RDF) replicated three times. The pearlmillet variety GHB-558, greengram variety GM-6, cowpea variety GC-5 and clusterbean Gujarat Guar 1 were used as a test varieties. Pearl millet was sown in paired rows at $30 \mathrm{~cm}$ keeping $60 \mathrm{~cm}$ distance between 2 pairs to adjust 1 row of intercrop. Fertilizer application was done on area basis as per treatment to only pearlmillet crops (RDF is 120-60-00 kg NPK/ha for pearlmillet). The plant height was measured using a metre scale from ground level to the tip of the main shoot randomly selected five tagged plants from each plot at 30, 60 DAS and at harvest and the mean values of height at each stage was expressed in $\mathrm{cm}$. The number of earheads in each of the tagged plants in all the plots were counted and averaged. Top, middle and bottom ear head girth were measured from five ear head of tagged plants by using vernier calliper and mean value was computed for each ear head of each treatment then average value per ear head was worked out for treatments. The length from the base to the apex of the ear head of main ear head of the five randomly selected plants for all the plots were measured with the help of scale. The mean value of five plants was worked out and registered. After harvesting in each net plot, the grains were threshed, cleaned and dried. The weight of grains in each plot was measured and expressed as $\mathrm{kg} / \mathrm{ha}$. After threshing, the weight of dried straw from each plot was recorded and expressed as $\mathrm{kg} / \mathrm{ha}$. The harvest index was calculated by dividing the economic yield by the biological yield and expressed as percentage $(\%)$.

\section{Harvest index \\ $=\frac{\text { Economic yield }}{\text { Biological yield }} \times 100$}

Analysis of variance for factorial randomized block design and significance of variance was tested by F-test (Gomez and Gomez, 1984). 
Critical difference for examining treatmental means for their significance was calculated at $5 \%$ significance.

\section{Results and Discussion}

\section{Yield Attributes of Pearlmillet}

The yield attributes for pearlmillet which were studied during our experiment during both the years were plant height, number of tillers per hill at 60 DAS and harvest, dry matter accumulation per plant at 60 DAS and harvest, number of ear heads per hill, ear head girth, number of earheads per hill, earhead girth and length (Table 1). The treatment $I_{2}$ (pearlmillet + greengram) recorded significantly taller pearlmillet plants which was at par with $\mathrm{I}_{3}$ (pearlmillet + cowpea). Similar results have also been reported Yadav et al., (2015) as well as Prathiksha and Dawson (2019) in pearlmillet based intercropping systems. These results were also in conformity with the findings of More number of ear head per hill in pearlmillet was obtained under sole pearlmillet treatment $\left(\mathrm{I}_{1}\right)$, it remained statistically at par with the treatments $I_{2}$ (pearlmillet + greengram).

These results were also in conformity with the findings of Kaluram and Meena (2014), Kumar et al., (2017). In case of fertility levels Significantly higher value of number of ear head per hill at harvest was observed with application of $125 \%$ RDF $\left(\mathrm{F}_{3}\right)$ which remained at par with treatments $\mathrm{F}_{2}$ (100\% RDF). Vari and Sadhu (2013) and Gaina (2014) reported that number of earhead per hill of pearlmillet increased with increase in $\mathrm{N}$ and $\mathrm{P}$ doses in intercropping system with pulses. Treatment with sole pearlmillet $\left(\mathrm{I}_{1}\right)$ produced significantly higher values of dry matter, it remained at par with treatments $\mathrm{I}_{2}$ (pearlmillet + greengram). Yield indices such as earhead girth and 1000 grain weight was not significantly influence by intercropping but in case of earhead length was significantly higher in sole pearlmillet and which was at par with $\mathrm{I}_{2}$ (pearlmillet + green gram).

This might be due to amount of nitrogen fixed by the component crop greengram which was fully utilized by the main crop pearlmillet for better growth and development resulted in expression of higher values of these yield indices. These results were also in conformity with the findings of Kumar et al., (2017), Baldev et al., (2018) and Goswami et al.,(2020). Pearlmillet crop are ferilized with $125 \%$ RDF recored significantly higher value of plant height, dry matter accumulations, earhead girth and length and which was at par with pearlmillet crop fertilized with $100 \%$ RDF. The similar result were obtained by Parihar et al., (2012) and Gaina (2014).

\section{Grain and straw yield of crops}

Effect of intercropping observed that the grain and straw yield of pearlmillet was significantly higher recorded with sole crop pearl millet $\left(\mathrm{I}_{1}\right)$ intercropping system, it remained statistically at par with the treatments $\mathrm{I}_{2}$ (pearlmillet + greengram). Similar results found that with Vari and Sadhu (2013), Kaluram and Meena (2014) and Goswami et al., (2020). Among the different fertility levels examined, significantly higher grain and straw yield of pearlmillet were recorded with application of $125 \% \mathrm{RDF}\left(\mathrm{F}_{3}\right)$ to pearlmillet crop.

Further, it remained statistically at par with the treatments $100 \%$ RDF $\left(\mathrm{F}_{2}\right)$. Higher dose of fertilization made the plants more efficient in photosynthetic activity and thereby enhancing carbohydrate metabolism in the plant. Finally the beneficial effects of all the attributes were reflected on the grain and straw yield per hectare. The result corroborate with the finding of Vari and Sadhu (2013), Gaina (2014). 
Table.1 Plant height, dry matter accumulations per plant, Number of ear head per hill, earhead girth, earhead length and test weight of pearlmillet as influenced by intercropping and fertility levels (Pooled data of two year)

\begin{tabular}{|c|c|c|c|c|c|c|c|c|}
\hline \multirow[t]{2}{*}{ Treatments } & \multicolumn{2}{|c|}{ Plant height } & \multicolumn{2}{|c|}{$\begin{array}{c}\text { Dry matter } \\
\text { accumulation (g) }\end{array}$} & \multirow{2}{*}{$\begin{array}{c}\text { Number of } \\
\text { Earheads } \\
\text { per hill }\end{array}$} & \multirow{2}{*}{$\begin{array}{c}\text { Earhead } \\
\text { Girth } \\
\text { (cm) }\end{array}$} & \multirow{2}{*}{$\begin{array}{l}\text { Earhead } \\
\text { length } \\
(\mathrm{cm})\end{array}$} & \multirow{2}{*}{$\begin{array}{c}\text { Test } \\
\text { weight } \\
\text { (g) }\end{array}$} \\
\hline & $\begin{array}{l}\text { At } 60 \\
\text { DAS }\end{array}$ & $\begin{array}{c}\text { At } \\
\text { harvest }\end{array}$ & At 60 DAS & At harvest & & & & \\
\hline \multicolumn{9}{|c|}{ Intercropping } \\
\hline $\mathbf{I}_{1}$ : sole crop pearl millet & 130.33 & 158.00 & 27.44 & 49.27 & 3.77 & 8.70 & 23.09 & 7.42 \\
\hline $\begin{array}{c}\mathbf{I}_{2}: \text { pearl millet + green } \\
\text { gram }\end{array}$ & 140.89 & 170.39 & 26.75 & 48.37 & 3.56 & 8.50 & 22.28 & 7.45 \\
\hline $\mathbf{I}_{3}$ : pearl millet + cowpea & 138.44 & 169.67 & 26.06 & 46.06 & 3.36 & 8.32 & 21.58 & 7.15 \\
\hline $\begin{array}{c}\mathbf{I}_{4}: \text { pearl millet }+ \text { cluster } \\
\text { bean }\end{array}$ & 129.17 & 158.17 & 24.82 & 45.14 & 2.96 & 8.20 & 20.84 & 7.05 \\
\hline SEm \pm & 2.27 & 2.75 & 0.44 & 0.79 & 0.083 & 0.17 & 0.522 & 0.15 \\
\hline $\mathrm{CD}(\mathrm{P}=\mathbf{0 . 0 5})$ & 6.47 & 7.84 & 1.26 & 2.25 & 0.24 & NS & 1.49 & NS \\
\hline \multicolumn{9}{|c|}{ Fertilizer levels } \\
\hline F1: $75 \%$ RDF & 128.67 & 156.88 & 25.21 & 45.38 & 2.86 & 8.04 & 20.58 & 7.17 \\
\hline F2: $100 \%$ RDF & 137.46 & 166.71 & 26.26 & 47.18 & 3.60 & 8.42 & 22.45 & 7.15 \\
\hline F3: $125 \%$ RDF & 138.00 & 168.58 & 27.35 & 48.95 & 3.80 & 8.83 & 22.82 & 7.49 \\
\hline $\mathrm{SEm} \pm$ & 1.97 & 2.38 & 0.38 & 0.68 & 0.07 & 0.14 & 0.45 & 0.13 \\
\hline $\mathrm{CD}(\mathrm{P}=\mathbf{0 . 0 5})$ & 5.60 & 6.79 & 1.09 & 1.95 & 0.20 & 0.41 & 1.29 & NS \\
\hline \multicolumn{9}{|c|}{ Interaction effect $(I \times F)$} \\
\hline SEm \pm & 3.93 & 4.76 & 0.76 & 1.37 & 0.143 & 0.29 & 0.903 & 0.26 \\
\hline $\mathrm{CD}(\mathrm{P}=\mathbf{0 . 0 5})$ & NS & NS & NS & NS & NS & NS & $\mathrm{NS}$ & NS \\
\hline Sig. interactions with Y & NS & NS & NS & NS & NS & NS & NS & NS \\
\hline $\mathrm{CV}(\%)$ & 7.15 & 7.11 & 7.13 & 9.14 & 10.27 & 8.33 & 10.08 & 8.70 \\
\hline
\end{tabular}


Table.2 Grain yield, straw yield and Pearlmillet grain equivalent yield of pearlmillet yield as influenced by intercropping and fertility levels (Pooled data of two year)

\begin{tabular}{|c|c|c|c|c|c|c|c|}
\hline \multirow[t]{2}{*}{ Treatments } & \multicolumn{2}{|c|}{ PearImillet } & \multicolumn{2}{|c|}{ Intercrop } & \multirow{2}{*}{$\begin{array}{c}\text { Pearlmillet } \\
\text { grain } \\
\text { equivalent } \\
\text { yield }\end{array}$} & \multirow{2}{*}{$\begin{array}{l}\text { Net return } \\
\text { (₹/ha) }\end{array}$} & \multirow[t]{2}{*}{ BCR } \\
\hline & $\begin{array}{l}\text { Grain } \\
\text { Yield } \\
\text { (kg/ha) }\end{array}$ & $\begin{array}{c}\text { Straw } \\
\text { yield } \\
\text { (kg/ha) }\end{array}$ & $\begin{array}{l}\text { Seed yield } \\
\text { (kg/ha) }\end{array}$ & $\begin{array}{c}\text { Stover } \\
\text { yield } \\
\text { (kg/ha) }\end{array}$ & & & \\
\hline \multicolumn{8}{|l|}{ A. Intercropping } \\
\hline $\mathbf{I}_{1}$ : sole crop pearl millet & 3002 & 5381 & - & - & 3002 & 30982 & 2.02 \\
\hline $\begin{array}{c}\mathbf{I}_{2}: \text { pearl millet + green } \\
\text { gram }\end{array}$ & 2978 & 5359 & 508 & 747 & 5575 & 66246 & 2.98 \\
\hline $\mathbf{I}_{3}$ : pearl millet + cowpea & 2474 & 4741 & 405 & 630 & 3646 & 44874 & 2.33 \\
\hline $\begin{array}{c}\mathbf{I}_{4}: \text { pearl millet }+ \text { cluster } \\
\text { bean }\end{array}$ & 2269 & 4097 & 281 & 795 & 3019 & 25189 & 1.76 \\
\hline SEm \pm & 42.89 & 90.68 & - & - & 52.42 & - & - \\
\hline $\mathrm{CD}(\mathrm{P}=\mathbf{0 . 0 5})$ & 122.26 & 258.46 & - & - & 149.43 & - & - \\
\hline \multicolumn{8}{|c|}{ B. Fertility levels } \\
\hline F1: $75 \%$ RDF & 2560 & 4671 & 288 & 523 & 3725 & 39916 & 2.26 \\
\hline F2: $100 \%$ RDF & 2741 & 4930 & 295 & 549 & 3770 & 42702 & 2.31 \\
\hline F3: $125 \%$ RDF & 2743 & 5081 & 312 & 556 & 3938 & 42852 & 2.27 \\
\hline SEm \pm & 37.15 & 78.53 & - & - & 45.40 & - & - \\
\hline $\mathrm{CD}(\mathrm{P}=\mathbf{0 . 0 5})$ & 105.88 & 223.84 & - & - & 129.41 & - & - \\
\hline \multicolumn{8}{|c|}{ Interaction effect $(I \times \mathbf{F})$} \\
\hline SEm \pm & 74.29 & 157.06 & - & - & 90.80 & - & - \\
\hline $\mathrm{CD}(\mathrm{P}=\mathbf{0 . 0 5})$ & 212 & 447.67 & - & - & 258.82 & - & - \\
\hline Sig. interactions with Y & NS & NS & - & - & NS & - & - \\
\hline
\end{tabular}


Table.3 Pearlmillet grain equivalent yield as influenced by interaction I X F

\begin{tabular}{|c|c|c|c|}
\hline \multirow[t]{4}{*}{ Intercropping (I) } & \multicolumn{3}{|c|}{ Pearlmillet grain equivalent yield (kg/ha) } \\
\hline & \multicolumn{3}{|c|}{2019} \\
\hline & \multicolumn{3}{|c|}{ Fertility levels (F) } \\
\hline & $\mathbf{F}_{1}$ & $\mathbf{F}_{2}$ & $\mathbf{F}_{3}$ \\
\hline $\mathbf{I}_{1}$ & 2911 & 3007 & 3115 \\
\hline $\mathbf{I}_{2}$ & 5500 & 5551 & 5600 \\
\hline $\mathbf{I}_{3}$ & 2933 & 3884 & 3973 \\
\hline $\mathbf{I}_{4}$ & 3434 & 2588 & 2962 \\
\hline \multirow[t]{3}{*}{$\mathrm{CD}(\mathrm{P}=\mathbf{0 . 0 5})$} & \multicolumn{3}{|c|}{354.35} \\
\hline & \multicolumn{3}{|c|}{2020} \\
\hline & $\mathbf{F}_{1}$ & $\mathbf{F}_{2}$ & $\mathbf{F}_{3}$ \\
\hline $\mathbf{I}_{1}$ & 2955 & 2906 & 3119 \\
\hline $\mathbf{I}_{2}$ & 5550 & 5601 & 5650 \\
\hline $\mathbf{I}_{3}$ & 3033 & 3983 & 4073 \\
\hline $\mathbf{I}_{4}$ & 3484 & 2638 & 3012 \\
\hline \multirow[t]{3}{*}{$\mathrm{CD}(\mathrm{P}=0.05)$} & \multicolumn{3}{|c|}{397.74} \\
\hline & \multicolumn{3}{|c|}{ Pooled } \\
\hline & $\mathbf{F}_{1}$ & $\mathbf{F}_{2}$ & $\mathbf{F}_{3}$ \\
\hline $\mathbf{I}_{1}$ & 2933 & 2957 & 3117 \\
\hline $\mathbf{I}_{2}$ & 5525 & 5576 & 5625 \\
\hline $\mathbf{I}_{3}$ & 2983 & 3934 & 4023 \\
\hline $\mathbf{I}_{4}$ & 3459 & 2613 & 2987 \\
\hline $\mathrm{CD}(\mathrm{P}=\mathbf{0 . 0 5})$ & \multicolumn{3}{|c|}{258.82} \\
\hline
\end{tabular}


Table.4 Economics of pearlmillet and intercropped crops as influenced by different treatment combinations (Average of 2019 and 2020)

\begin{tabular}{|c|c|c|c|c|c|c|c|c|c|}
\hline \multirow{2}{*}{$\begin{array}{l}\text { Sr. } \\
\text { No. }\end{array}$} & \multirow{2}{*}{$\begin{array}{l}\text { Treatment } \\
\text { combination }\end{array}$} & \multirow{2}{*}{$\begin{array}{c}\text { Total cost } \\
\text { of } \\
\text { cultivation }\end{array}$} & \multicolumn{2}{|c|}{ PearImillet } & \multicolumn{2}{|c|}{ Intercrops } & \multirow{2}{*}{$\begin{array}{l}\text { Gross } \\
\text { return }\end{array}$} & \multirow{2}{*}{$\begin{array}{l}\text { Net } \\
\text { return }\end{array}$} & \multirow[t]{2}{*}{ BCR } \\
\hline & & & $\begin{array}{c}\text { Grain } \\
\text { yield } \\
\text { (kg/ha) }\end{array}$ & $\begin{array}{c}\text { Straw } \\
\text { yield } \\
\text { (kg/ha) }\end{array}$ & $\begin{array}{c}\text { Seed } \\
\text { yield } \\
(\text { kg/ha) }\end{array}$ & $\begin{array}{c}\text { Stover } \\
\text { yield } \\
\text { (kg/ha) }\end{array}$ & & & \\
\hline 1 & $\mathrm{I}_{1} \mathrm{~F}_{1}$ & 29048 & 2933 & 5186 & - & - & 59553 & 30505 & 2.05 \\
\hline 2 & $\mathrm{I}_{1} \mathrm{~F}_{2}$ & 30195 & 2957 & 5353 & - & - & 60414 & 30219 & 2.00 \\
\hline 3 & $\mathrm{I}_{1} \mathrm{~F}_{3}$ & 31341 & 3117 & 5603 & - & - & 63564 & 32223 & 2.02 \\
\hline 4 & $\mathrm{I}_{2} \mathrm{~F}_{1}$ & 32287 & 2908 & 5166 & 501 & 709 & 97378 & 65091 & 3.01 \\
\hline 5 & $\mathrm{I}_{2} \mathrm{~F}_{2}$ & 33424 & 2912 & 5322 & 507 & 762 & 98565 & 65141 & 2.94 \\
\hline 6 & $\mathrm{I}_{2} \mathrm{~F}_{3}$ & 34570 & 3115 & 5591 & 516 & 769 & 103078 & 68508 & 2.98 \\
\hline 7 & $\mathrm{I}_{3} \mathrm{~F}_{1}$ & 32455 & 2358 & 4533 & 390 & 600 & 75069 & 42614 & 2.31 \\
\hline 8 & $\mathrm{I}_{3} \mathrm{~F}_{2}$ & 33593 & 2755 & 4141 & 400 & 638 & 80619 & 47026 & 2.39 \\
\hline 9 & $\mathrm{I}_{3} \mathrm{~F}_{3}$ & 34738 & 2310 & 5549 & 425 & 650 & 79722 & 44984 & 2.29 \\
\hline 10 & $\mathrm{I}_{4} \mathrm{~F}_{1}$ & 31991 & 2040 & 3799 & 264 & 784 & 53445 & 21454 & 1.67 \\
\hline 11 & $\mathrm{I}_{4} \mathrm{~F}_{2}$ & 33129 & 2339 & 4908 & 272 & 796 & 61551 & 28422 & 1.85 \\
\hline 12 & $\mathrm{I}_{4} \mathrm{~F}_{3}$ & 34274 & 2430 & 3583 & 305 & 804 & 59967 & 25693 & 1.74 \\
\hline
\end{tabular}




\section{Pearlmillet grain equivalent yield}

Pearlmillet grain equivalent yield was Significantly the highest was produced when pearlmillet was intercropped with greengram $\left(\mathrm{I}_{2}\right)$ as compared to other intercropping systems and sole pearlmillet. The highest pearlmillet equivalent yield due to pearlmillet + greengram system could be attributed to the higher market price of greengram. These finding are in conformity with those reported by Vari and Sadhu (2013), Ghilotia et al., (2015), Yadav et al., (2015) and Goswami et al., (2020). Among the different fertility levels examined, significantly higher grain equivalent yield of pearlmillet were recorded with application of $125 \% \operatorname{RDF}\left(\mathrm{F}_{3}\right)$ to pearlmillet crop. Further, it remained statistically at par with the treatments $100 \%$ $\operatorname{RDF}\left(\mathrm{F}_{2}\right)$ in both the year. These finding are in conformity with those reported by Vari and Sadhu (2013) and Gaina (2014).

Data in Table 4 indicated that treatment combination with pearlmillet + greengram $\left(\mathrm{I}_{2}\right)$ and $125 \%$ RDF to pearlmillet $\left(\mathrm{I}_{2} \mathrm{~F}_{3}\right)$ applied to pearlmillet registered the highest grain equivalent yield of pearlmillet. But it was found statistically at par with treatment combinations $\mathrm{I}_{2} \mathrm{~F}_{2}$ and $\mathrm{I}_{2} \mathrm{~F}_{1}$. These results are in accordance with the results of Vari and Sadhu (2013) and Kumar et al., (2017).

\section{Economics}

Among the different intercropping treatments, pearlmillet + greengram $\left(\mathrm{I}_{2}\right)$ secured the maximum net realization of ₹ 66246/ha and BCR of 2.98. Amongst the fertility levels, pearlmillet fertilized with $125 \% \operatorname{RDF}\left(\mathrm{F}_{3}\right)$ secured highest net returns of ₹ 42852/ha with BCR of 2.27 .

The results of present experiment it can be concluded that for achieving higher yield and net returns, intercropping of pearl millet + green gram (2:1 row ratio) along with $75 \%$ recommended dose of fertilizers (90-45-00 $\mathrm{N}+\mathrm{P}_{2} \mathrm{O}_{5}+\mathrm{K}_{2} \mathrm{O} \mathrm{kg} / \mathrm{ha}$ ) to pearl millet crop should be followed during summer season under south Gujarat condition.

\section{References}

Baldev, R., Chaudhary, G. R. and Jat, A. S. (2018). Effect of integrated nutrient management and intercropping systems on growth and yield of summer pear millet (Pennisetum glaucum L.). Indian J. of Agron. 16 (1):71-76.

Gaina, G. K., Sharma, O. P., Shivram, A. C., Boori, P. K. and Meena, S. S. (2014). Productivity and nutrient uptake of pearlmillet influenced by intercropping with legumes and fertility level. Res. Envs. Life sci., 10 (3): 209-212.

Ghilotia, Y. K., Meena, R. N. and Lakhapati Singh. (2015). Pearlmillet and mungbean intercropping as influenced by various row ratios under custard apple orchard of Vindhyan region. The Bioscan. 10 (1): 87 - 91.

Goswami, A. L., Kalyanasundaram, N. K., Patel, I, S., Patel, J. M., Patel, S. I. and Patel, B. M. (2020). Effect of additive serie in intercropping system with pearl millet. Annals of Arid Zone. 37 (1):69-74.

Kaluram and Meena, R. S. (2014). Evaluation of pearlmillet and mungbean intercropping systems in arid region of Rajasthan (India). Bangladesh $J$. of Botany. 43 (3):367 - 370.

Kumar, M. A., Rana, K. S. and Kumar, P. K. (2017). Effect of intercropping and fertility levels on summer pearl millet (Pennisetum glaucum). Indian J. of Agron. 56 (3):209-216

Ofori F, Stern W R. Cereal \pm legume intercropping system. Advances in Agronomy. 1987; 41:41-90. 
Parihar, C. M., Rana, K. S., Jat, M. L., Jat, S. L., Parihar, M. D., Kantwa, S. R., Singh D. K. and Sharma, S. (2012). Carbon footprint and economic sustainability of pearlmillet-mungbean system under different tillage and nutrient management practices in moisture stress conditions. African Journal of Microbiology Research, 6 (23), PP. 5052-5061.

Prathiksha, K. L. and Dowson, A. P. (2019). Effect of intercropping and nitrogen levels on growth, yield and yield attributes of pearlmillet (Pennisetum glaucum L.). Indian J. Agron. 16 (3): 210-213.

Reddy M S, Willy R W. Growth and resource use studies in an intercrop of pearlmillet/groundnut. National Symposium, Indian Society of Agronomy, CSSRI, Karnal, 3-5 April, 1980, New Delhi, 1981.
Swaminathan M S. Crop production and sustainable food security. In Chopra V. L., Singh R. B. and Verma A. (eds). Crop Productivity and Sustainability Shaping the Future. Proceedings of the Second International Crop Science Congress, New Delhi, India, 1998, 318.

Vari, S. D and Sadhu, A. C. (2013). Influence of row ratios and fertility levels on yield attributes and yield of pearlmillet - greengram intercropping system and nutrient status of the soil. International $J$. of Forestry and Crop Improvement. 3 (2): 144-146.

Yadav, B. L., Patel B. S., Shaukat Ali and Yadav, S. K. (2015). Intercropping of legumes and oilseed crops in summer pearlmillet [Pennisetum glaucum L.) R. Br. Emend. Stuntz]. Legume Research. 38 (4): 503-508.

\section{How to cite this article:}

Patel, K. R., J. D. Thanki and Kalal, P. H. 2021. Effect of Intercropping and Fertility Levels on Yield Attributes, Yield and Economics of Summer Pearlmillet (Pennisetum glaucum L.) under South Gujarat Condition. Int.J.Curr.Microbiol.App.Sci. 10(06): 597-605. doi: https://doi.org/10.20546/ijcmas.2021.1006.065 